\title{
The Diary of a Disaster: Behrouz Boochani's 'asylum in space'
}

\author{
Gillian Whitlock
}

A diary is not only a place of asylum in space; it is also an archive in time.... Phillipe Lejeune (On Diary 324)

On Autobiography is a selection of eleven essays translated into English from Philippe Lejeune's major studies, Le Pacte autobiographique, Lire Leiris, autobiographie et langage, Je est un autre and Moi aussi. In his editorial Foreword Paul John Eakin remarks that some of the range and authority of Lejeune's studies of autobiography have been lost in translation. As a result, recognition of his contribution to autobiography studies as an historian, critic and theorist remains limited, and criticism in English tends to focus on the formalist and generic orientation of his early work on the autobiographical pact. What goes missing are the social and historical dimensions of his work on autobiography, and his enduring interest in 'micro-forms' of autobiographical discourse and the work that they do: how does autobiographical discourse circulate today? who engages in it? who reads it? where does it come from? (xxii). For postcolonial scholarship in particular, Lejeune's questions about how 'those who are controlled' become agents in the creation of life narratives endure. Philippe Lejeune is himself always meticulous about the social, historical and cultural focus of his research in Western modernity, and specifically in France-he is tentative, for example, when asked to address a conference on autobiography and life writing in Algeria, but he welcomes the opportunity to think about how his study of the diary in France might be applied to other countries with very different cultures (On Diary 267). For postcolonial criticism, his work remains instrumental and thought-provoking, and here I want to emphasise the currency of Lejeune's writing in thinking about one of the critical issues in life narrative studies now: how refugees 
and asylum seekers enter public discourse to engage a witnessing public and engender compassion, mobilise shame, and inspire campaigns for social justice on their behalf (Whitlock, Postcolonial Life Narratives, 168).

Eakin's selection of essays in On Autobiography includes the English translation of 'The Autobiography of Those Who Do Not Write', introducing this critical essay to a wider readership in 1989. 'Who Is the Author?', Lejeune asks, turning towards narratives where the presence of ghostwriters and collaborators blurs the singularity and authenticity of the authorial signature, and the power relations embedded in the production and marketing of life narratives as 'cultural goods' is evident. A brilliant turn of phrase emerges through translation here: leafing through the mass of biographies, accounts, memoirs and souvenirs archived in the Catalogue de l'histoire de France, Lejeune hears the 'ground noise' of French society in the nineteenth century. These are the voices 'of those who have succeeded, whose life has some social value' in the life of the nation (199). 'The personal life of the controlled classes ....is not in their hands' he writes, and turns to his colleague Pierre Bourdieu: 'the controlled classes do not speak, they are spoken' (199).

How do life stories enable 'the controlled classes' to disrupt that 'ground noise', that audible life of the nation? How do ghost-writers, collaborators, editors, archivists, critics further collaborate in controlling the production and dissemination of subaltern life stories, as 'messengers of the ruling classes' (214)? How does the marketing and consumption of the life story of 'someone who does not write' participate in the desire for 'the postcolonial exotic'? (Huggan). 'The common desire ... is to see, and to make seen, what is hidden from sight', writes Lejeune, 'to grasp what cannot be grasped, to constitute as the object of knowledge a kind of absolute other' (207). This interrogation of how life stories of 'those who do not write' become a commodity for those who have the power to write and read, and how even the most benevolent and humanitarian interventions participate in violation and voyeurism, returns to questions of communicative ethics and critical practice that recur in Lejeune's writings - and beyond that in postcolonial literary and cultural criticism more generally. Discourses of nation and narration are the 'ground noise' that renders life stories of 'the controlled classes'-workers and immigrants, indigenous peoples and the enslaved-inaudible.

What are we to do about this? Lejeune has two suggestions. The first is a transformation where intellectuals themselves become the focus of interrogation, and the disciplines that participate in the production and dissemination of life stories-ethnography, anthropology, history, literature-reflect on scholarly critical practice. This is the kind of critical autoethnographical work we see in work on indigeneity and life 
narrative in Canada, Australia and South Africa, for example (Shostak, Aodla Freeman, Muecke, van Toorn, Grossman), although Lejeune is invoking not only self-reflexive scholarly work but also projects where 'those who are controlled' become agents rather than subjects of representation. The second reversal he identifies in 'The Autobiography of Those Who Do Not Write' is technological innovations that transform the 'noise' by turning away from writing and printing to other technologies. For example, audiovisual life stories transform the power relations that control the circulation and reception of life stories of those who do not write. In 1989 (when this selection of essays is published) neither Lejeune nor Eakin can anticipate the revolutionary change in the production and reception of life story that will be produced by the internet, however, Lejeune would be one of the first to engage with these new technologies of the self.

By the time I was writing my book on life writing and the 'war on terror', Soft Weapons (2007), Lejeune's Cher Écran....Journal personnel, ordinateur, Internet (2000) inspired the chapter on Where is Raed?, Salam Pax's weblog from Baghdad. The idea that reading digital texts requires new styles of reading and critical practice, and that digital diaries are interactive, forking, hybrid texts that reconfigure representations of the self, opens the way to distinctively online reading practices of 'browsing' and 'surfing' that Lejeune puts to work in Cher écran in his daily record of horizontal reading that this new technology demands. Where is Raed? can be read diachronically, following the life of the mysterious Salam Pax as he narrates the invasion of Baghdad in the spring of 2003 in real time. From his home in Baghdad, Pax offers an eyewitness account of the invasion and occupation of Iraq. As Lejeune suggests, the momentum of weblogs is synchronic and dialogic. This introduces the diary as a process of engagement in real time. Cher écran emphasises the transformative possibilities of the almost simultaneous act of diary writing online and the act of reading, a new interactive component to the production and reception of diary that is used by Pax to engage in a practice of communicative ethics, creating a polemical and tactical intervention into debates about the war on terror and the invasion of Iraq. The synchronicity of the diary online produces a concatenation across various lives captured at a moment in time. Pax's identity is provisional and shaped by crisis, and he uses the weblog to rehearse the practice of a democratic Iraqi citizenship in the absence of the structures of a democratic state. In a time of crisis and chaos, Pax uses new media-the only public space available to him-to practise his ideological commitment to processes of deliberative democracy: an open and ongoing public discussion about social justice and human rights (Soft Weapons, 42). 
Like the publication of Eakin's edition of On Autobiography in 1989, the English translation of Lejeune's On Diary (2009), a selection of his essays on diary and diary writing as a cultural practice, many translated into English for the first time, has brought a vibrant new collection of Lejeune's criticism into transnational scholarly networks in English, and these essays are written with an intimacy and candour born of his deep, first-hand attachment to diary as a diarist himself. The final essay, 'Lucullus Dines With Lucullus', is conversational, candid, returning to Lejeune's boyhood fascination with the Roman general and the beginnings of his own personal diary on October 11, 1953, when he was 15 years old: 'Lucullus reminded me of Phillipus-myself-and you will soon see why' (330). The diary is an intimate confidante, 'It was up to me to show myself some hospitality. I sought refuge in paper' (331). At the age of 14, his experience of the world was transformed when he was sent to a sanatorium to recover from illness: 'I discovered the violence of the world. I was bullied and sometimes beaten ...For the first time I invented a private language - a fairly rudimentary one - that was meant for me alone ... in this way, I would be able to recall, and perhaps write about, my hell.' (331) The diary is a kind of 'auto-hospitality', a kindness to the self, 'an asylum in space' (334).

Recently, late in 2017, an asylum seeker, Behrouz Boochani, also turned to diary in search of sanctuary. This is not the private, intimate turn to auto-hospitality of the boy Phillipus, but it is a turn to diary born of an experience of hell, a response to the unexpected violence of the world in an institutional space where asylum was sought, and it is an appeal for hospitality. Boochani is a refugee, one of men on Manus detained at the Australian Regional Processing Centre on Manus Island in Papua New Guinea, where those who arrive in Australia by boat in search of asylum are held in mandatory detention. Boochani is a journalist, an Iranian of Kurdish ethnicity. What kinds of self-representation become available to him? How do refugees in detention interrupt the 'ground noise' of aggressive nationalism that attaches their non-freedom to narratives of the sovereignty of the nation and the defence of Australian citizenship? Boochani is a resourceful public intellectual as well as a detainee in this remote camp. He maintains a Facebook page and a Twitter account; he is the co-producer of the film 'Chauka. Please Tell Me the Time', filmed by him using his smartphone in the camp; he writes commentaries for the international media; he is the author of autobiographical essays about the camp anthologised by humanitarian activists; and he is the most readilyrecognisable public face of the men in detention on Manus.

For a brief time, from 25 October to November 2017, Behrouz writes the 'Diary of a Disaster' in a series of dated instalments from the camp 
that are translated into English and published in The Guardian online. This is tactical. The timeline in the first diary entry on 25.10.17 indicates why: in April 2016 the camp on Manus was ruled illegal and unconstitutional by the Papua New Guinea Supreme Court, and in August the Australian government confirms the centre will close. None of the 854 men detained there will be resettled in Australia, they must accept repatriation, resettlement in PNG or, for a select few, the opportunity to resettle in the USA following an exchange agreement negotiated by the outgoing Obama administration. Now, more than a year later when the Disaster Diary begins, the men occupy the camp and resist relocation, uncertain of the security of the alternative accommodation on the island. For a brief time, they resist and create a community that survives in defiance, asserting their human rights. After they are finally forcibly removed, Behrouz draws this period that is chronicled in the diary to a close with a letter from Manus Island that is published on the front page of the Australian newspaper The Saturday Paper: a poet's manifesto of the refugee resistance. This 'Diary of a Disaster' is a chronicle of the occupation, a performative space where the diary narrative enables a visceral and intimate account of their resistance, "we are now one of the most forgotten people on earth' he writes, in a turn to Fanon (30.10.17).

'I woke up from a nightmare today', the diary begins, and it sustains an intimate disclosure of embodied experience: disgust as he uses the stinking toilets and cold shower; weariness of writing about people who have died; fear as the camp is submerged into a 'state of terror' as the police threaten to intervene with force; uncertainty as he ushers journalists into the camp and worries what they will make of what they see. The 'Disaster Diary' is one of a series of 'feeds' Behrouz sustains simultaneouslyTwitter, Facebook, and interviews with journalists in Australia, Europe and the USA. What the diary brings to this assemblage of autobiographical accounts of the camp is a confessional rawness and intimate self-display, the trademark of diary as a strategic and rhetorical device (Cardell 13) that enables the militant Boochani to bear witness to an historic if brief resistance on behalf of the many in the camp who remain unnamed and unknown.

Like Salam Pax, Boochani turns to web diary to write out of a state of siege, to write of his belly and his bowels, and create an intimate chronicle, an 'archive in time' (On Diary 324), when recognition of him as a human being fails. Here, in this context, Philippe Lejeune's essay on the 'hospitality' of the diary is an opportunity to consider how refugees, 'those who are controlled', those who are located as 'the absolute other' on the periphery, might find asylum in the most inhospitable spaces to which they are consigned. The 'Diary of a Disaster' uses the synchronicity 
of the online diary to intervene in the 'ground noise' that is now strident and aggressive, a rhetoric that identifies asylum seekers as objects of fear and disgust. Behrouz Boochani and the asylum seekers on Manus are, of course, remote in place and time from 'those who do not write', and from Phillipus, who seeks refuge in paper. Nevertheless, Lejeune's association of diary with asylum, and hospitality, comes alive here as the 'Diary of a Disaster' takes that fleeting opportunity that Lejeune entertains at the end of 'The Autobiography of Those Who Do Not Write': here, for a brief time, refugees initiate their own 'instant history' in a work of emancipation.

\section{WORKS CITED}

Aodla Freeman, Mini. Life Among the Quallunaat. Ed. Keavy Martin. Winnipeg: University of Manitoba Press, 2015.

Boochani, Behrouz. "Diary of Disaster: The Last Days inside Manus Island Detention Centre." Sydney Australia The Guardian. 30 October. https://www.theguardian.com/ commentisfree/2017/oct/30/diary-of-disaster-the-last-days-inside-manus-island-detention-centre? CMP=share_btn_link Accessed 15.1.18, 2017a.

Boochani, Behrouz. "A Letter from Manus Island." The Saturday Paper 9-15 December, pp 1, 4. https://www.thesaturdaypaper.com.au/news/politics/2017/12/09/letter-manus-island/15127380005617. Accessed 23.3.18, 2017b.

Cardell, Kylie. De@r World. Contemporary Uses of the Diary. Madison: University of Wisconsin Press, 2014.

Grossman, Michele. Entangled Subjects: Indigenous/Australian Cross-Cultures of Talk, Text, and Modernity. Amsterdam: Rodopi, 2013.

Huggan, Graham. The Postcolonial Exotic: Marketing the Margins. New York: Routledge, 2001.

Lejeune, Phillippe. On Autobiography. Ed. Paul John Eakin. Trans. Katherine Leary. Minneapolis: University of Minnesota Press, 1989.

Lejeune, Phillippe. Cher Écran....Journal Personnel, Ordinateur, Internet. Paris: Seuil, 2000.

Lejeune, Phillippe. On Diary. Ed. Jeremy D. Popkin and Julie Rak. Trans. Katherine Durnin. Honolulu: University of Hawai'i Press, 2009.

Muecke, Stephen, Paddy Roe and Krim Benterrak. Reading the Country. Introduction to Nomadology. Sydney: Re Press, 2014.

Shostak, Marjorie. Nisa. The Life and Words of a !Kung Woman. Cambridge, MA: Harvard University Press, 2000.

Van Toorn, Penny. Writing Never Arrives Naked. Early Aboriginal Cultures of Writing in Australia. Canberra: Aboriginal Studies Press, 2006.

Whitlock, Gillian. Soft Weapons. Autobiography in Transit. Chicago: University of Chicago Press, 2007.

Whitlock, Gillian. Postcolonial Life Narratives. Testimonial Transactions. Oxford: Oxford University Press, 2015. 


\section{ABOUT THE AUTHOR}

Gillian Whitlock is Professor of English at the University of Queensland, and a Fellow of the Australian Academy of the Humanities. She is the author of 'Postcolonial Life Narrative' (Oxford 2016), 'Soft Weapons: Autobiography in Transit' (Chicago 2007) and 'The Intimate Empire' (Bloomsbury 2000), as well as numerous edited books, book chapters and articles on postcolonialism and life narrative. She is currently writing a book on refugees in detention based on archives from the Pacific camps. 